\title{
THE 'VERRUCARIA FUSCELLA GROUP' IN POLAND WITH SOME NOMENCLATORIAL REMARKS
}

\author{
BEATA KRZEWICKA \\ Laboratory of Lichenology, W. Szafer Institute of Botany \\ Polish Academy of Sciences \\ Lubicz 46, 31-512 Kraków, Poland \\ e-mail: b.krzewicka@botany.pl
}

(Received: March 2, 2009. Accepted: June 29, 2009)

\begin{abstract}
The Verrucaria fuscella group in Poland is revised. Two species, Placopyrenium fuscellum and Verrucaria polysticta, are confirmed for Poland, and Placopyrenium canellum is reported for the first time. Dermatocarpon subfuscellum var. serpentini Servít is synonymized with $P$. fuscellum and $V$. fuscella f. subpruinosa Servít is synonymized with $V$. polysticta.
\end{abstract}

KEY WORDS: Placopyrenium canellum, P. fuscellum, Verrucaria polysticta, Poland, synonymization.

\section{INTRODUCTION}

The species of the $V$. fuscella group are characterized by a well-developed superficial thallus divided into small and separate areoles angular in outline, with distinct black sides and the upper surface marked by dark lines. They have at least a partially dark brown pigmented medulla. Perithecia are without an involucrellum and are completely immersed in the thallus. Some species initially grow on thalli of members of the $V$. nigrescens group and on some species of the genus Aspicilia, later becoming independent and occurring mainly on calcareous rocks in sunny places or rarely on siliceous rocks in moist habitats (Orange 2009).

In a recent revision of the $V$. fuscella group in Great Britain and Ireland (Orange 2004), three species are accepted: $V$. canella (with its synonyms $V$. aspiciliicola $R$. Sant. and $V$. aspiciliae Zehetl.), V. fuscella (syn. V. glebulosa Nyl.) and $V$. polysticta (with synonyms $V$. fuscella var. nigricans Nyl., $V$. nigricans, and $V$. subfuscella). However, recent molecular phylogenetic analyses and morphological studies have shown that it is necessary to revise the present morphology-based generic delineation of the lichen family Verucariaceae in order to account for evolutionary relatedness between species (Gueidan et al. 2007, 2009; NavarroRosinés et al. 2007). According to Navarro-Rosinés et al. (2007) molecular phylogenetic analyses have shown that two species from $V$. fuscella group, such as $V$. canella and $V$. fuscella belong to Placopyrenium (Breuss 2009), whereas $V$. polysticta is nested in the Endocarpon group and is recognized as 'Verrucaria' polysticta (Gueidan et al. 2007, 2009).
In Poland members of the $V$. fuscella group have been reported as species of the genera Verrucaria, Lithoicea and Dermatocarpon. The first historical data on the species from Poland were published by Körber (1855), who reported $V$. fuscella (Turner) Winch as a frequent species in $\mathrm{Si}$ lesia. In his lichen monograph of Silesia, Stein (1879) listed the typical Lithoicea fuscella Turner together with the form glaucina Ach. No new records were added until 1927 when Motyka reported V. glaucina in the Tatra Mts (Motyka 1927).

The interest in the group in Central Europe intensified in this period. Zschacke (1934) discussed as many as nine species: V. acrotelloides A. Massal., V. alutacea Wallr., $V$. canella Nyl., V. controversa A. Massal., $V$. fuscella, $V$. glaucina, V. nigricans (Nyl.) Zschacke, V. polysticta Borrer and V. subfuscella Nyl. According to Servít, some of the species reported by Zschacke in fact belong to Dermatocarpon. He therefore changed their status and proposed new combinations, for example D. subfuscellum (Servít 1936), D. glaucinum (Servít 1952) and D. subpruinosum (Servít 1946), for the form $V$. fuscella f. subpruinosa Servít (Servít 1936). However, at present the name $V$. glaucina (syn. D. glaucinum) is excluded from the $V$. fuscella group by Fröberg (1989) because the type material of $V$. glaucina in UPS and $\mathrm{H}-\mathrm{ACH}$ was recognized as $V$. caerulea DC. As found in this study, some the specimens published under the name $V$. glaucina in Europe belong to the $V$. fuscella group.

The contemporary history of the species from $V$. fuscella group in Poland is quite complicated. Members of the group have often been confused and either oppositely named or incorrectly determined as V. glaucina. In their mono- 
graph of lichens, Porosty Polskie, Nowak and Tobolewski (1975) correctly differentiated the taxa referred to as $V$. fuscella and $V$. polysticta. However, the authors used unspecific key characters for the taxa and misplaced figures showing both species (figure 19b named $V$. fuscella belongs to $V$. polysticta, while figure 33 named Dermatocarpon subfuscellum shows $P$. fuscellum). Additionally, the name $V$. nigricans was included as a synonym of $V$. fuscella in regional and national checklists following Wirth (1995) (Bielczyk 2003; Fałtynowicz 2003). Fałtynowicz (2003) mistakenly reported the name $V$. polysticta as a synonym of $V$. caerulea in the Polish checklist of lichens. The synonimization was most likely unintended as may be concluded based on the synonyms quoted by the author.

A taxonomic revision of the species from $V$. fuscella group in Poland is urgently needed for the above reasons. Two species, Placopyrenium fuscellum and Verrucaria polystic$t a$, are confirmed for Poland in this study, while one, Placopyrenium canellum, is reported for the first time.

\section{MATERIAL AND METHODS}

The study is based on the material from Polish herbaria (GPN, KRAM, KRAP, KTC, POZ, WRSL). The original collections as well as other reference specimens from KRAM, NMW, PRM were also studied. The material was examined using standard microscopic techniques. Thallus anatomy was investigated using handmade sections mounted in water. All measurements were made in water.

The distribution of species in Poland is discussed and mapped using exclusively documented data; other data are not considered in this paper. The ATPOL system was used to code the data on the maps using Gnomon 3.3.

\section{RESULTS AND DISCUSSION}

\section{Placopyrenium canellum (Nyl.) Gueidan \& Cl. Roux}

in Navarro-Rosinés et al., Bull. Soc. Linn. Provence 58: 174. 2007. - Verrucaria canella Nyl., Flora 66: 102. 1883.

Prothallus absent or indistinct, black. Thallus superficial, well developed, 260-600 $\mu \mathrm{m}$ thick, cracked, areoles separated by deep cracks, angular in outline, plane or slightly concave, pale grey to brownish, pruinose, 120-800(-1100) $\mu \mathrm{m}$ diam. Upper surface subdivided by dark lines. Margin thin, initially not broken into discrete areas, but very early divided by cracks. Medulla colourless to densely pigmented, often occupying half of thallus thickness. Algal layer continuous to dissected by brown pigmented medulla parts, algae up to 5-7 $\mu \mathrm{m}$ diam., arranged in well-defined columns. Perithecia 1-3(-5) per mature areole, immersed, ostiole visible as a small depression. Involucrellum absent. Exciple 150-280 $\mu \mathrm{m}$ wide, colourless to brown below. Asci 8 -spored. Ascospores colourless, simple, narrowly oblongellipsoid, (18-)20-23(-28) × 6-7(-10) $\mu \mathrm{m}$, perispore present, sometimes difficult to distinguish from ascospore wall. Conidiomata not detected in material examined.

Note. The species is distinguished from $P$. fuscellum and $V$. polysticta by the larger ascospores $(20-23 \times 6-7 \mu \mathrm{m})$ and the presence of a perispore. Young thalli of $P$. canellum are additionally parasitic on Aspicilia sp. Placopyrenium canellum may have spores growing up to $32 \mu \mathrm{m}$ according to
Zschacke (1934). Zschacke also distinguished this species by a whitish medulla using this feature as a key character. Orange (2004) observed a range of pigmentation, from colourless to densely pigmented, in P. canellum in Great Britain. A similar range was observed in the material from Poland.

REMARKS. Although P. canellum was described from Wales more than one hundred years ago as $V$. canella $(\mathrm{Ny}-$ lander 1883), the taxon was for a long time ignored and neglected by lichenologists. Only Zschacke (1934) mentioned the species as occurring in $\mathrm{N}$ Wales and $\mathrm{N}$ England in a monograph of Verrucariaceae from Central Europe. According to Orange (2004), the taxon was re-described by Zehetletiner (1978) from Croatia as V. aspiciliae Zehetl., a parasitic species on Aspicilia calcarea occurring in the eastern part of the European Mediterranean Basin and in England. Subsequently the name $V$. aspiciliae was a synonymised with $V$. canella (Orange 2004).

ECOLOGY AND DISTRIBUTION. In Poland $V$. canella was found on Aspicilia calcarea growing on unshaded calcareous in mountain regions in Gorce Mts and Pieniny Mts (Fig. 1). This is the first report of the species from Poland. It has been reported in Europe from scattered localities in the Mediterranean Basin as well as in France, Hungary, Sweden, England and Wales (Zehetleiner1978; Orange 2004).

Specimens examined: Poland: EG-22 - Gorce Mts, Ochotnica Dolna Borysiówka village, S slope of the Twarogów hill, 520 m, 5 Aug. 1999, P. Czarnota (GPN 2255) as V. fuscella; EG-33 - Pieniny Mts, Wąwóz Sobczański, on calcareous rocks 680 m, 1 Sept. 1981, J. Pyrek \& Z. Toborowicz (KTC) as $V$. subfuscella.

Additional specimens examined. France: Côte d'Or, Fleurey-sur-Ouche, 01.1959, ? (KRAM-L 18567); Great Britain: Wales: V.C. 49, Caernarvonshire, Great Ormes Head, 23/7.8, 1927, D. A. Jones (NMW 44.64.1352).

Placopyrenium fuscellum (Turner) Gueidan \& Cl. Roux

in Navarro-Rosinés et al., Bull. Soc. Linn. Provence 58: 174 (2007). - Lichen fuscellus Turner, Trans. Linn. Soc.

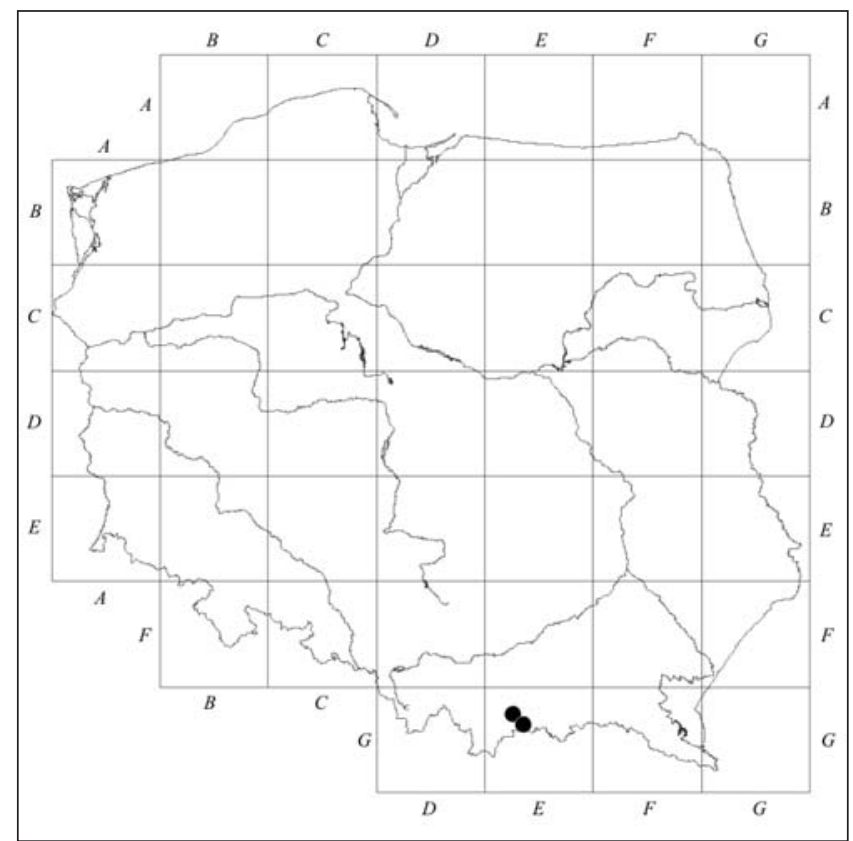

Fig. 1. Distribution map of Placopyrenium canellum (Nyl.) Gueidan \& Cl. Roux in Poland. 
London 7: 90, tab. VIII, fig. 2. 1804. - Verrucaria fuscella (Turner) Winch, The Botanist's Guide 2: 45. 1807.

Dermatocarpon subfuscellum var. serpentini Servít, Beih. Bot. Centralb. 55: 270. 1936. Type: Moravia, Mohelno in rup. serpentini ca. $300 \mathrm{~m}, 1927$, J. Suza (PRM! syntype) Dermatocarpon serpentini (Servít) Servít, Stud. Bot. Cechoslov. 7(2-4): 57. 1946.

Prothallus absent or indistinct. Thallus superficial, well developed, 250-800 $\mu \mathrm{m}$ thick, cracked, young areoles angular elongate, 100-200 × 300-600, mature areoles separated by deep cracks, angular in outline, (300-)500-1000 $\times$ 700-1000(-2000) um diam. Upper surface of mature areoles divided into smaller angular units by dark lines, pruinose. Medulla densely pigmented. Algal layer dissected by brown pigmented medulla parts, algae up to 7-10 $\mu \mathrm{m}$ diam., arranged in well-defined columns; photosynthetic units with perithecia often 3-4 times thicker than units without perithecia. Perithecia $0.2-0.3 \mathrm{~mm}$, a few present in the same photosynthetic unit; ostiole appearing at thallus surface as brownish spot 20-50(-80) $\mu \mathrm{m}$ wide. Involucrellum absent. Exciple colourless to dilute brown below, 150$-290 \mu \mathrm{m}$ wide, immersed in photosynthetic units, occasionally flanked by dark pigmented medulla. Asci 8-spored. Ascospores colourless, simple, oblong-ellipsoid 12-15 $\times$ 5.5-7.0 $\mu \mathrm{m}$, perispore absent. Conidiomata not detected in material examined.

NoTE. Placopyrenium fuscellum differs from $V$. polystic$t a$ in angular, elongate areoles with the upper surface usually sparsely marked by dark lines, perithecia not flanked by dark medulla arising in the photosynthetic units with ostioles appearing at the thallus surface as spots up to 20$-50(-80) \mu \mathrm{m}$ wide. It differs from $P$. canellum in smaller ascospores without a perispore.

REMARKS. Servít (1936) distinguished Dermatocarpon subfuscellum var. serpentini by areoles uniformly pruinose and distinctly black-bordered but it is treated here as a synonym of $P$. fuscellum. The type collection of the variety (PRM 858284) has a well-developed thallus, up to 250-800 $\mu \mathrm{m}$ thick and cracked with areoles separated by deep cracks and angular in outline. Areoles are marked by dark lines in outline and on the upper surface. Exciples of perithecia are colourless except ostioles appearing at the thallus surface as brownish to blackish spots. Ascospores are without a perispore and are 12-15 × 5.5-7.0 $\mu \mathrm{m}$. Morphological and anatomical analyses show that the taxon is conspecific with $P$. fuscellum.

ECOLOGY AND DISTRIBUTION IN POLAND. This species occurs on exposed, sunny natural calcareous rocks. Young individuals of the species are parasitic on thalli of $V$. nigrescens while mature ones become independent. Recorded from the Sudety Mts (Pogórze Izerskie Foothills and Góry Kaczawskie Mts) and the Carpathian Mts (Beskid Średni Mts, Gorce Mts, Pieniny Mts, Beskid Sądecki Mts Beskid Niski Mts and Bieszczady Mts) in the south. It was also found in the Góry Świętokrzyskie Mts, the Wyżyna Wieluńska Upland and the Wyżyna Krakowsko-Częstochowska Upland in central Poland (Fig. 2).

In Poland, the name $V$. fuscella has been reported in many publications (see Fałtynowicz 2003). Some records of $P$. fuscellum are confirmed for the following: Sudety Mts (Kossowska 2008), Jura Krakowsko-Częstochowska Upland (Nowak 1961), Pieniny Mts (Kiszka 1997, 2001) and Bieszczady Mts (Glanc and Tobolewski 1960) [see

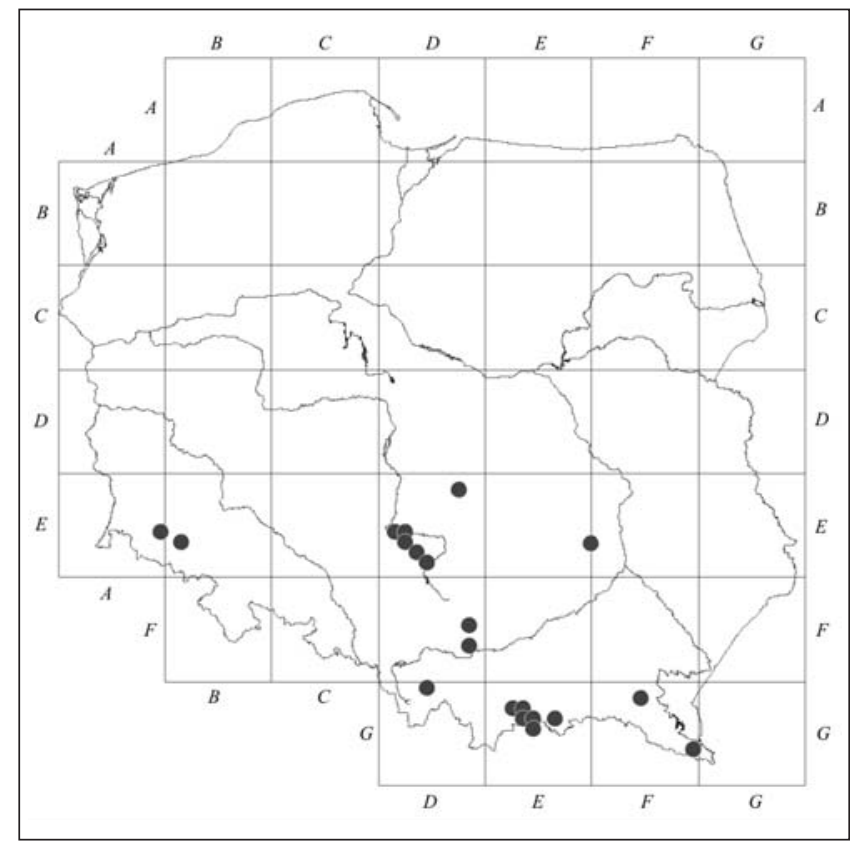

Fig. 2. Distribution map of Placopyrenium fuscellum (Turner) Gueidan \& Cl. Roux In Poland.

specimens examined]. However, some other records represent $V$. polysticta [see under the species]. The species distribution presented here on a map (Fig. 2) is discussed exclusively on documented data.

Specimens examined: Poland: AE-59 - Pogórze Izerskie foothills, Pilchowice, Wapniak Mt., 1997, M. Kossowska (WRSL); BE-61 - Góry Kaczawskie Mts, Wojcieszów, 610 m, 6 Sept. 1978, J. Nowak (KRAM-L 22914) as $V$. subfuscella; Wojcieszów, Miłek Mt., 1988, A. Zalewska (WRSL); DE-51 - Wyżyna Wieluńska Upland, Węże near Działoszyn, 20 May 1963, J. Nowak (KRAM-L 43172) as V. subfuscella; Węże near Działoszyn, 8 Oct. 1971, J. Nowak (KRAM-L 34526) as V. nigricans; DE-52 - Wyżyna Wieluńska Upland, Zalesiaki near Działoszyn, 1 June 1963, J. Nowak (KRAM-L 43170) as D. subfuscellum; Szklana Góra near Działoszyn, 2 May 1965, J. Nowak (KRAM-L 21503) as D. subfuscellum; DE-62 - Wyżyna Wieluńska Upland, Łobodno near Kłobucko, 2 June 1964, J. Nowak (KRAM-L 63168) as D. subfuscellum; DE-73 Wyżyna Wieluńska Upland, Kamyk near Kłobucko, 21 May 1964, J. Nowak (KRAM-L 43169) as D. subfuscellum; DE-84 - Wyżyna Krakowsko-Częstochowska Upland, between Olsztyn and Przymiłowice, 4 July 1963, J. Nowak (KRAM-L 34609); DF-17 - Wyżyna Krakowsko-Częstochowska Upland, Berkowa Góra, 10 June 1974, J. Nowak (KRAM-L 17630) as D. subfuscellum; DF-48 Wyżyna Krakowsko-Częstochowska Upland, Dolina Prądnika valley, Ojców National Park, 30 April 1956, J. Nowak (KRAM-L 18606); DF-68 - Wyżyna Krakowsko-Częstochowska Upland, Dolina Bolechowicka valley, 10 Oct. 1956, J. Nowak (KRAM-L 19312); Nieplice near Rudawa, 320 m, 30 Sept. 1986, J. Nowak (KRAM-L 30436); DG-04 - Beskid Średni Mts, Koleby near Żywiec, 400 m, 21 Sept. 1965, J. Nowak (KRAM-L 13490) as V. subfuscella; EG22 - Gorce Mts, Ochotnica Dolna Borysiówka, S slope of the Twarogów hill, 520 m, 5 Aug. 1999, P. Czarnota (GPN 2041) as $V$. subfuscella; S slope of the Twarogów hill, 9 Sept. 1960, K. Glanc (KRAM-L 38596); S slope of the Twarogów hill, 680 m, 14 July 1966, K. Glanc (KRAM-L 
35727); EG-23 - Gorce Mts, near Ochotnica Dolna Michałki, 430 m, 5 Aug. 1999, P. Czarnota (GPN 2208); Lubań Mt., E slope of Baszta hill, 480 m, 27 Aug. 1967, K. Glanc (KRAM-L 35725); EG-33 - Pieniny Mts, Wąwóz Sobczańsk gorge, on calcareous rocks 580 m, 6 Aug. 1954, Z. Tobolewski (POZ); Małe Pieniny Mts, Stolarzówka, 742 m, 24 June 1982, J. Pyrek \& K Toborowicz (KTC) as $V$. subfuscella; EG-34 - Małe Pieniny Mts, Mała Woda nature reserve, 2 June 1999, J. Kiszka (KRAP) as V. subfuscella; EG-44 - Małe Pieniny Mts, Wysoki Kamień nature reserve, 12 Aug. 2008, J. Kiszka (KRAP) as V. subfuscella; EG-36 - Beskid Sądecki Mts, Żebracze nature reserve, 810 m, 5 July 2001, P. Czarnota (GPN 2581) as V. subfuscella; FE-70 - Góry Świętokrzyskie Mts, Ćmielów near Ostrowiec Świętokrzyski, 19 Aug. 1971, J. Nowak (KRAML 19899, 22407) as V. subfuscella; FG-14 - Beskid Niski Mts, Sieniawa village, by Wisłok river on sandstone, 315 m, 20 Aug. 1974, J. Nowak (KRAM-L 33306); FG-69 Bieszczady Mts, Bereżki, 650 m, 25 Sept. 1959, K. Glanc (KRAM-L 24207).

Additional specimens examined: Bulgaria: Pirin Mts, Bayovi Doupki, 21 Sept. 1975, J. Nowak (KRAML 35203); Czech Republic: Moravia, Mohelno. 260-300 m, 1927 \& 1930, J. Suza (PRM 858274, 858275, 858283, 858284, 858285); Great Britain: England: V.C. 69, Westmorland, Asby. Great Asby Scar National Nature Reserve, 35/65.10 and 64.10, 2006, B. Krzewicka 3138 (KRAML 50212, 50225); England: V.C. 70, Cumberland, Keswick, River Greta, Calvert's Bridge, 35/2743.2385, 2006, B. Krzewicka 3054 (KRAM-L 50224); Ukraine: Podilskyi Tovtry National Park, Kitaihorod, 15 km SE of Kamianest Podilsky, 24 June 2003, P. Czarnota 3700 (KRAML 48670).

\section{Verrucaria polysticta Borrer}

Engl. Bot. Suppl. 2: plate 2741. 1834.

Verrucaria fuscella f. subpruinosa Servít, Beih. Bot. Centralb. 55: 253. 1936. Type: Styria. Kraubath, Gulsen, in rup. Serpentin. 24.6.1931. J. Suza. (PRM syntype!) - Dermatocarpon subpruinosum (Servít) Servít, Stud. Bot. Cechoslov. 7(2-4): 62. 1946. - Verrucaria subpruinosa (Servít) auct.

Verrucaria fuscella var. nigricans Nyl., Flora 64: 189. 1881. - Verrucaria nigricans (Nyl.) Zschacke, Rabenh. Kryptog.-Fl. 9: 274. 1934.

Verrucaria subfuscella Nyl., Lich. Scand.: 271. 1861. Dermatocarpon subfuscellum (Nyl.) Servít, Beih. Bot. Centralb. 55: 270. 1936.

Prothallus present, blackish, non-fimbriate. Primary areoles arising on prothallus. Thallus superficial, well developed, 280-700(-1000) $\mu \mathrm{m}$ thick, cracked, areoles separated by deep cracks, mature areoles 300-1100 diam., multiangular in outline, plane or slightly concave. Upper surface grey or light brown to brown, pruinose or not, usually marked by dark lines. Medulla densely pigmented, often occupying half or more of thallus thickness (50-)100-200 $\mu \mathrm{m}$. Algal layer dissected by brown pigmented parts of medulla, algae up to 7-10 $\mu \mathrm{m}$ diam., arranged in well-defined columns. Perithecia immersed, 1-6(-9) per areole, arising between the photosynthetic units, rarely within one of the units; ostiole appearing at thallus surface as brownish to black, slightly concave disc 100-260 $\mu \mathrm{m}$ wide. Involucrellum absent. Exciple dark brown, usually flanked by dark medulla,
150-290 $\mu \mathrm{m}$ wide. Asci 8-spored. Ascospores colourless, simple, oblong-ellipsoid or ellipsoid, 12-15 × 5.5-7.0 $\mu \mathrm{m}$, perispore absent. Conidiomata not detected in material examined.

Note. The species is distinguished from $P$. canellum by smaller ascospores without perispores. It differs from $P$. fuscellum in multi-angular areoles with the upper surface usually richly marked by dark lines, perithecia flanked by dark medulla, mostly arising between photosynthetic units, ostioles appearing at the thallus surface as disc-shaped up to $100-260 \mu \mathrm{m}$ wide.

REMARKS. Servít (1936) distinguished $V$. fuscella f. subpruinosa by the ash-grey to whitish, +/- pruinose upper surface of the thallus. The description in the protologue was rather vague and emphasized misleading characters. The type collection of the form subpruinosa (PRM 645359) is characterised by a well-developed thallus growing up to 500$-700 \mu \mathrm{m}$, with the upper surface marked by dark lines, and mature areoles having 3-4 perithecia flanked by dark medulla with ostioles appearing at the thallus surface as brownish to blackish discs $100-150 \mu \mathrm{m}$ wide and by ascospores $12-15 \times 5.5-7.0 \mu \mathrm{m}$. Both $V$. fuscella f. subpruinosa and $V$. polysticta are characterized by the same features. Therefore the name Verrucaria fuscella f. subpruinosa is proposed here to be synonymized with $V$. polysticta.

Some recent checklist (e.g. Vězda and Liška 1999, Fałtynowicz 2003) have used the name V. subpruinosa Servít, but this apparently not validly published.

ECOLOGY AND DISTRIBUTION IN POLAND. This species grows on calcareous rocks in sunny places. In Poland $V$. polysticta occurs in areas with large natural limestone outcrops, i.e. in the Wyżyna Krakowsko-Częstochowska Upland, the Pieniny Mts and the Western Tatra Mts. It grows at scattered localities on calcareous sandstones in the Bieszczady Mts and Beskidy Zachodnie Mts within the Polish Carpathians. It was recorded in the Góry Świętokrzyskie Mts outside the Carpathians (Fig 3). Verrucaria polysticta has been published in Poland mainly under the name $V$. subfuscella and $V$. nigricans or mistaken as $V$. fuscella (see Tobolewski 1965; Fałtynowicz 2003), and the occurrence of the species is confirmed here for the following regions: Jura Krakowsko-Częstochowska Upland (Nowak 1961), Gorce Mts (Czarnota 2000), Pieniny Mts (Kiszka 1997, 2001). However, it is worth noting that $V$. polysticta has also been mistaken with $P$. fuscellum.

Specimens examined: Poland: DF-48 - Wyżyna Krakowsko-Częstochowska Upland, Dolina Sąspowska valley, Ojców National Park, 9 Aug. 1957, J. Nowak (KRAML 21368) as V. nigricans; Dolina Sąspowska valley, Ojców National Park, 6 Aug. 1957, J. Nowak (KRAM-L 19313, 19330) as V. fuscella; DF-58 - Wyżyna Krakowsko-Częstochowska Upland, Dolina Kobylańska valley, 6 Aug. 1957, J. Nowak (KRAM-L 21373) as V. nigricans; near Rudawa, 280 m, 9 Oct. 1971, J. Nowak (KRAM-L 29978) as V. fuscella; DF-68 - Wyżyna Krakowsko-Częstochowska Upland, Dolina Brzoskwinki valley, Tenczyński Landscape Park, 13 Sept. 1957, J. Nowak (KRAM-L 21366) as V. nigricans; Nieplice near Rudawa, 280 m, 30 Sept. 1986, J. Nowak (KRAM-L 30448) as V. fuscella; DF-97 - Beskid Makowski Mts, Skawce, 300 m, 6 Sept. 1995, U. Bielczyk \& R. Kozik (KRAM-L 42568) as V. fuscella; DG-04 - Beskid Średni Mts, Pasmo Pewelskiego range, Łyska, 400 m, 21 Sept. 1965, J. Nowak (KRAM-L 12133) as $V$. 


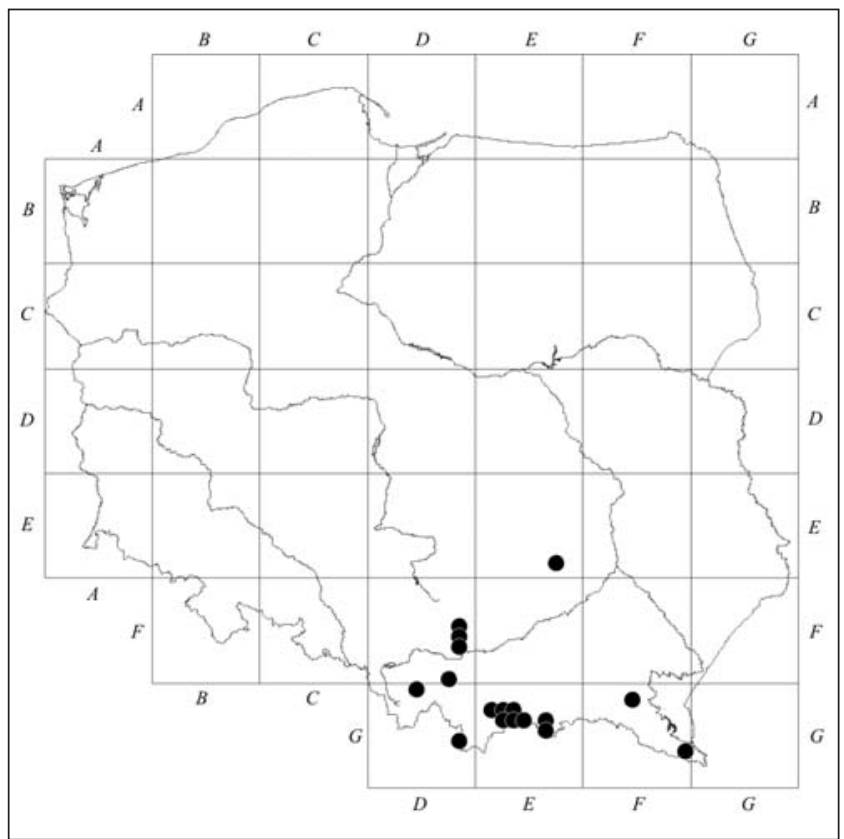

Fig. 3. Distribution map of Verrucaria polysticta Borrer in Poland.

fuscella; DG-58 - Tatry Zachodnie Mts. Bobrowiec Mt., 1400 m, Aug. 1982, K. Toborowicz (KTC) as V. glaucina; EE-87 - Góry Świętokrzyskie Mts, Łagów, old quarry, 24 April 1982, K. Toborowicz \& I. Wrocławska (KTC) as $V$. subfuscella; EG-21 - Gorce Mts, below the Średniak meadow 1080 m, 3 Sept. 1997, P. Czarnota (GPN 1614/94) as V. fuscella; EG-22 - Gorce Mts, Ochotnica Dolna, Borysiówka, S slope of the Twarogów hill, 600 m, 10 May 1959, K. Glanc (KRAM-L 35720) as V. fuscella; S slope of the Twarogów hill, $680 \mathrm{~m}$, 9 Sept. 1960, K. Glanc (KRAM-L 38595, 35729) as V. nigricans; S slope of the Twarogów hill, 740 m, 5 July 1967, K. Glanc (KRAML 35722) as V. fuscella; S slope of the Twarogów hill, 680 m, 9 Sept. 1966, K. Glanc (KRAM-L 19245) as V. nigricans; EG-23 - Gorce Mts, Lubań Mt., S slope of Makowica hill, 620 m, 4 Aug. 1968, K. Glanc (KRAM-L 24206, 35721) as V. fuscella; EG-32 - Pieniny Mts, Sromowce Wyżne, Pulsztyn Mt. 605 m, Aug. 1981, K. Toborowicz (KTC) as V. subfuscella; EG-33 - Pieniny Mts, Wąwóz Sobczański gorge, on calcareous rocks, 580 m, 6 Aug. 1954, Z. Tobolewski (POZ) together with V. fuscella; Wąwóz Sobczański gorge, 600 m, 4 May 1957, J. Nowak (KRAM-L 18605) as V. fuscella; Wąwóz Sobczański gorge, 720 m, 2 Sept. 1981, K. Toborowicz (KTC) as V. subfuscella; Wąwóz Sobczański gorge, on calcareous rocks 680 m, 1 Sept. 1981, J. Pyrek \& Z. Toborowicz (KTC) as V. subfuscella; Sromowce Niżne, Grabczycha by Dunajec river, 450 m, 24 Sept. 1980, K. Toborowicz (KTC) as $V$. subfuscella; Sromowce Niżne, Grabczycha by the Dunajec river, 529 m, 22 June 1982, K. Toborowicz (KTC) as $V$. subfuscella; Wąwóz Homole gorge, on calcareous rocks 11 Sept. 1959, J. Nowak (KRAM-L 21204) as V. nigricans; EG-34 - Beskid Sądecki Mts, Pasmo Radziejowej range, Kamień św. Kingi rocks, 1100 m, 18 Aug. 1960, J. Nowak (KRAM-L 21465) as V. fuscella; EG-36 - Beskid Sądecki Mts, Żebracze nature reserve, 810 m, 5 July 2001, P. Czarnota (GPN 2601) as V. fuscella; EG-46 - Beskid Sądecki Mts, Żegiestów, ? (KRAM-L 10791, 10792) as V. fuscella; FG-14 - Beskid Niski Mts, Sieniawa village, by Wisłok ri- ver on sandstone, 315 m, 20 Aug. 1974, J. Nowak (KRAML 33329); FG-69 - Bieszczady Mts, Bereżki, 650 m, 25 Sept. 1959, K. Glanc (KRAM-L 35723) as V. fuscella.

Additional specimens examined: Bulgaria: Bleak Sea coast, near Varna, Aladzha monastery, 2 Aug. 1962, J. Nowak (KRAM-L 9346); Great Britain: England: V.C. 69, Westmorland, Asby. Great Asby Scar National Nature Reserve, 35/65.10 and 64.10, 2006, B. Krzewicka 3140 (KRAM-L 50227).

\section{ACKNOWLEDGMENTS}

I am grateful to Dr. hab. Lucyna Śliwa (Kraków) for her valuable advice, to Dr. Joanna Kazik (Łódź) for her useful remarks on the manuscript and help with the English. Thanks are also due to the curators of the lichen herbaria NMW, PRM and GPN, LBL, LOD, KRAM, KRAP, KTC, OLTC, POZ and WRSL for their help.

\section{LITERATURE CITED}

BIELCZYK U. 2003. The lichens and allied fungi of the Polish Carpathians. In: U. BIELCZYK (ed.), The lichens and allied fungi of the Polish Carpathians - an annotated checklist. W. Szafer Institute of Botany, Polish Academy of Sciences, Kraków, pp. 295-342.

BREUSS O. 2009. A synopsis of the lichen genus Placopyrenium (Verrucariaceae), with description of new taxa and a key to all species. Biblioth. Lichenol. 99: 93-112.

CZARNOTA P. 2000. Porosty Gorczańskiego Parku Narodowego. Część I. Wykaz i rozmieszczenie gatunków. Parki Nar. Rez. Przyr. 19(1): 3-73. (in Polish)

FAŁTYNOWICZ W. 2003. The lichens, lichenicolous and allied fungi of Poland - an annotated checklist. Biodiversity of Poland 6. W. Szafer Institute of Botany, Polish Academy of Sciences, Kraków. pp. 435.

FRÖBERG L. 1989. The Calcicolous Lichens on the Great Alvar of Öland, Sweden. Institutionen för Systematisk Botanik, Lund, pp. 109.

GLANC K., TOBOLEWSKI Z. 1960. Porosty Bieszczadów Zachodnich. Poz. Tow. Przyj. Nauk, Wydz. Mat.-Przyr. Prace Kom. Biol. 21(4): 1-108. (in Polish with English summary)

GUEIDAN C., ROUX C., LUTZONI F. 2007. Using a multigene phylogenetic analysis to assess generic delineation and character evolution in Verrucariaceae (Verrucariales, Ascomycota). Mycol. Res. 111: 1147-1170.

GUEIDAN C., SAVIĆ S., THÜS H., ROUX C., KELLER C., TIBELL L., PRIETO M., HEIĐMARSSON S., BREUSS O., ORANGE A., FRÖBERG L., AMTOFT W.A., NAVARROROSINÉS P., KRZEWICKA B., PYKÄLÄ J., MARTIN G., LUTZONI F. 2009. Generic classification of the Verrucariaceae (Ascomycota) based on molecular and morphological evidence: recent progress and remaining challenges. Taxon 58(1): 184-208.

KISZKA J. 1997. Porosty (Lichenes) dna i otoczenia zbiorników retencyjnych w dolinie Dunajca w Pieninach. Fragm. Flor. Geobot., Ser. Polonica 4: 253-323. (in Polish with English summary)

KISZKA J. 2001. Porosty(Lichenes) rezerwatu przyrody "Przełom Białki pod Krempachami" na Podhalu (Karpaty Zachodnie). Chrońmy Przyrodę Ojczystą 57(3): 11-31. (in Polish)

KOSSOWSKA M. 2008. Lichens growing on calcareous rocks in the Polish part of the Sudety Mountains. Acta Botanica Silesiaca, Monographiae 3: 1-108.

KÖRBER G.W. 1855. Systema Lichenum Germaniae. Die Flechten Deutschlands mikroscopisch geprüft, kritisch gesichtet, 
charakteristisch beschrieben und systematisch geordnet. Verlag von Trewendt \& Granier, Breslau, pp. 460.

MOTYKA J. 1927. Materiały do flory porostów Tatr. Część II. Spraw. Kom. Fizjogr. PAU 61: 1-16. (in Polish)

NAVARRO-ROSINÉS P., ROUX C., GUEIDAN C. 2007. La genroj Verrucula kaj Verruculopsis (Verrucariaceae, Verrucariales). Bull. Soc. Linn. Provence 58: 133-180.

NOWAK J. 1961. Porosty Wyżyny (Jury) Krakowsko-Częstochowskiej. Monogr. Bot. 11(2): 1-128. (in Polish)

NOWAK J., TOBOLEWSKI Z. 1975. Porosty polskie. Opisy i klucze do oznaczania porostów w Polsce dotychczas stwierdzonych lub prawdopodobnych. PWN, Warszawa-Kraków, pp. 1177. (in Polish)

NYLANDER W. 1883. Addenda nova ad Lichenographiam Europaeam. Continuatio quadragesima. Flora 66: 97-109.

ORANGE A. 2004. The Verrucaria fuscella group in Great Britain and Ireland. Lichenologist 36: 173-182.

ORANGE A. 2009. Two parasitic species of Placopyrenium (Verrucariaceae) from freshwater habitats in north-west Europe. Lichenologist 41: 131-139.

SERVÍT M. 1936. Neue und seltenere Flechten aus den Familien Verrucariaceae und Dermatocarpaceae. Beih. Bot. Centralbl. 55: 251-274.
SERVÍT M. 1946: The new lichens of the Pyrenocarpae-Group. I. Studia Bot. Cechoslov. 7: 49-111.

SERVÍT M. 1952: Nové a málo známé druhy z čeledí Verrucariaceae a Dermatocarpaceae. Preslia 24: 345-390.

STEIN B. 1879. Flechten. In: Kryptogamen-Flora von Schlesien. Im Namen der Schles. Ges. f. vaterländ. Kultur herausgeg. v. Prof. Dr. Ferd. Cohn. Jahresber. Schles. ges. f. vaterl. Cultur 2: $1-400$.

TOBOLEWSKI Z. 1965. Wykaz porostów dotychczas stwierdzonych w Polsce (wraz z bibliografią lichenologiczną). Poz. Tow. Przyj. Nauk, Wydz. Mat.-Przyr. Prace Kom. Biol. 24(3): 1-61. (in Polish with English summary)

WIRTH V. 1995. Die Flechten Baden-Württembergs, Teil 2. Eugen Ulmer GmbH \& Co., Stuttgart, pp. 1006.

VËZDA A., LIŠKA J. 1999. A catalog of lichens of the Czech Republic. Institute of Botany Academy of Sciences of Czech Republic, Průhonice, pp. 283.

ZEHETLEITNER G. 1978. Über einige parasitische Arten der Flechtengattung Verrucaria. Nova Hedwigia 29: 683-734.

ZSCHACKE H. 1934. Epigloeaceae, Verrucariaceae und Dermatocarpaceae. In: Dr. L. Rabenhorst's Kryptogamen-Flora von Deutschland, Österreich und der Schweiz. Die Flechten. Akademische Verlagsgesellschaft M. B. H., Leipzig. pp. 695. 